\title{
IMPLEMENTASI LESSON STUDY PADA MATA KULIAH PENGANTAR LOGIKA DI STKIP MUHAMMADIYAH KOTABUMI
}

\author{
Venty Meilasari *)
}

\begin{abstract}
Pengantar logika which focus on teacher-centered learning leads to the lack of student involvement in learning. This study aims to describe the application of learning models TAI-based lesson study and see the impact on improving student learning activities. Application of lesson study consists of three stages: planning, implementation (do), and reflection (see). Open lesson implementation is done three times. Based on the findings of the observers, the application of lesson study is able to shift the learning paradigm from teacher-centered to student-centered. This is indicated by the more dominant student activity in learning and increasing student activity every cycle.
\end{abstract}

\section{Keyword: Application, TAI, lesson study, student activity}

\section{PENDAHULUAN}

Pengantar logika merupakan salah satu mata kuliah yang wajib ditempuh mahasiswa pendidikan matematika di STKIP Muhammadiyah Kotabumi. Mata kuliah ini menjadi dasar bagi mata kuliah lainnya. Dalam mata kuliah ini, mahasiswa mempelajari mengenai dasar bagaimana cara berpikir yang benar yang nantinya digunakan untuk membuktikan suatu validitas argumen, menyimpulkan argumen, atau membuktikan kebenaran dari suatu teorema.

Selama ini pembelajaran pada mata kuliah pengantar logika masih bersifat teacher centered. Dalam pembelajaran, dosen masih menjadi sumber belajar utama. Hal ini mengakibatkan kurangnya keterlibatan mahasiswa dalam pembelajaran. Mahasiswa hanya menunggu informasi dari dosen sehingga ketika diberikan variasi soal yang berbeda, mahasiswa akan mengalami kesulitan dalam penyelesaiannya. Menurut Yamin (2013:26) belajar merupakan proses mahasiswa secara aktif untuk membangun pengetahuannya. Sebaiknya pembelajaran yang diterapkan menuntut keterlibatan mahasiswa yang lebih dominan.

Salah satu alternatif mengatasi masalah praktik pembelajaran yang kurang efektif, yaitu Lesson Study. Menurut Rusman (2011:383) lesson study merupakan suatu upaya pembinaan untuk meningkatkan proses pembelajaran yang dilakukan oleh sekelompok guru atau dosen secara kolaboratif dan berkesinambungan dalam merencanakan, melaksanakan, mengobservasi, dan merefleksi kegiatan pembelajaran. Selanjutnya, Wang-Iverson 
dan Yoshida dalam Sukirman (2006:7) pengetahuan tentang pemahaman berpikir dan menyebutkan bahwa lesson study belajar siswa, dan 6) meningkatkan memberikan manfaat sebagai berikut: 1) kemampuan kolaborasi/kooperatif pada mengurangi keterasingan guru, 2) membantu sesama pendidik, sesama peserta didik, guru untuk mengobservasi dan mengkritisi pendidik dan peserta didik.

pembelajarannya, 3) memperdalam Dalam implementasinya, menurut pemahaman guru tentang materi pelajaran, Indonesia Mathematics and Science Teacher cakupan dan urutan materi dalam kurikulum, Education Project (IMSTEP) (JICA) (2006) 4) membantu guru memfokuskan bantuannya lesson study terdiri atas tiga tahapan, yaitu: pada seluruh aktivitas belajar siswa, 5) perencanaan (plan), pelaksanaan (do), dan menciptakan terjadinya pertukaran refleksi (see).

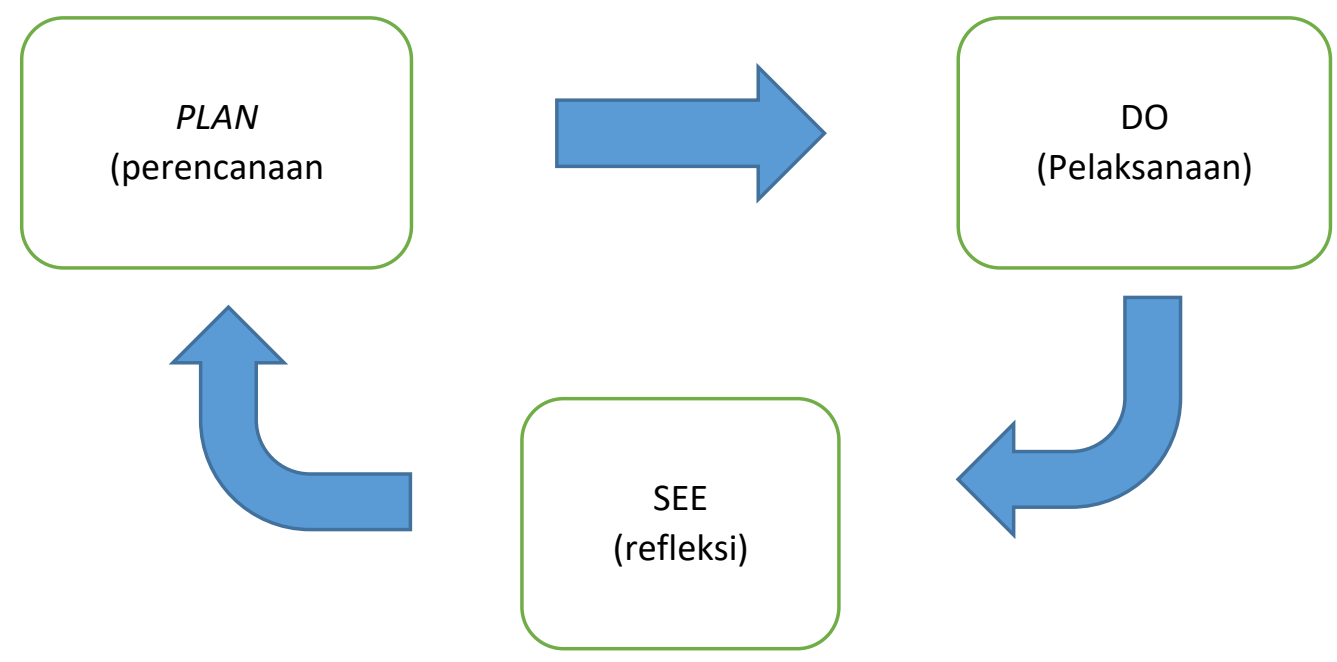

(Sumber: IMSTEP, JICA, 2006)

Gambar 1. Alur Lesson Study

Tahap plan bertujuan untuk merancang Perencanaan diawali dengan analisis pembelajaran yang akan dilaksanakan. permasalahan yang dihadapi dalam Pembelajaran yang baik adalah pembelajaran pembelajaran. Selanjutnya dosen/guru secara yang dapat membuat mahasiswa dapat bersama mencari solusi dari permasalahan berpartisipasi secara aktif. Hendayana yang dihadapi, yang dituangkan dalam (2007:11) menyatakan perencanaan bertujuan rancangan pembelajaran atau lesson design, untuk merancang pembelajaran yang berpusat media pembelajaran, dan lembar kerja serta pada mahasiswa (student center). metode evaluasi. Setelah perangkat Perencanaan sebaiknya tidak dilakukan pembelajaran dirumuskan, dilakukan evaluasi sendirian, melainkan dilakukan bersama mengenai perangkat pembelajaran yang akan dengan rekan-rekan dosen atau guru. digunakan. Selain itu, dilakukan briefing 
mengenai rencana pembelajaran sebelum dilakukannya proses $d o$.

Selanjutnya tahap do merupakan tahapan penerapan rencana yang telah dirumuskan pada lesson design. Pada tahap do, terdapat observer yang ikut mengamati pembelajaran dalam kelas. Fokus yang diamati, yaitu interaksi mahasiswa dengan mahasiswa, mahasiswa dengan bahan ajar, mahasiswa dengan dosen, dan mahasiswa dengan lingkungan.

Tahapan terakhir pada lesson study, yaitu see. Setelah selesai melakukan tahap do, dosen model melakukan diskusi dengan para observer. Diskusi ini diawali dengan dosen model menyampaikan kesan-kesan dalam pelaksanaan pembelajaran yang telah dilalui. Selanjutnya, observer diminta menyampaikan komentar lesson learn dari pembelajaran, terutama berkenaan dengan aktivitas siswa dalam pembelajaran. Perbaikan pembelajaran berikutnya didasarkan dari masukan yang telah diberikan oleh para observer.

Penerapan lesson study diharapkan dapat memperbaiki pembelajaran yang kurang efektif. Selanjutnya, karena dalam penerapannya fokus utama yang diamati adalah aktivitas siswa, pembelajaran kolaboratif menjadi salah satu pilihan model yang dapat diterapkan. Dalam pembelajaran kolaboratif, mahasiswa bekerja dalam kelompok-kelompok kecil yang heterogen. Karena mata kuliah pengantar logika mempunyai variasi soal atau permasalahan yang banyak, model pembelajaran Team Assisted Individualization (TAI) dapat dijadikan salah satu model pembelajaran kolaboratif yang diterapkan.

Model pembelajaran kooperatif tipe TAI merupakan model pembelajaran yang menggabungkan teknik pembelajaran tertentu untuk mengatasi permasalahan pembelajaran individual dan meningkatkan keterampilan kooperatif mahasiswa. Slavin (2005:187) menyatakan bahwa tujuan dari model pembelajaran TAI, yaitu untuk mengadaptasi pengajaran terhadap perbedaan individu yang berkaitan dengan kemampuan siswa maupun pencapaian prestasi siswa. Pada pembelajaran ini mahasiswa belajar dalam kelompok heterogen yang terdiri dari empat sampai lima orang. Dalam kelompok, mahasiswa tidak hanya bertanggung jawab atas keberhasilan individu, tetapi juga keberhasilan kelompok. Dengan demikian, diharapkan mahasiswa dapat saling membantu dalam memahami materi pelajaran sehingga tercapai hasil belajar kelompok yang maksimal.

Berdasarkan uraian di atas, dapat dirumuskan tujuan penelitian ini, yaitu "mendeskripsikan penerapan model pembelajaran TAI berbasis lesson study serta melihat dampaknya pada peningkatan aktivitas belajar mahasiswa".

\section{METODE PENELITIAN}

Metode yang digunakan dalam penelitian ini, yaitu metode deskriptif kualitatif. Metode 
deskriptif kualitatif menurut Sugiyono (2010:15) adalah metode penelitian yang berlandaskan pada filsafat positivisme. Metode ini digunakan untuk meneliti pada kondisi objek yang alamiah (sebagai lawannya, yaitu eksperimen). Peneliti sebagai instrumen kunci. Pengambilan sampel sumber data dilakukan secara purposive dan snowball, teknik pengumpulan dengan trianggulasi. Analisis data bersifat induktif/kualitatif. Hasil penelitian kualitatif lebih menekan makna daripada generalisasi.

Implementasi lesson study dilakukan pada tanggal 5 s.d. 19 Oktober 2017, di ruang 9 gedung AR Fahrudin STKIP Muhammadiyah Kotabumi. Subjek penelitian, yaitu mahasiswa semester I yang berjumlah 47 orang. Namun, tidak semua mahasiswa hadir dalam setiap pelaksanaan pembelajaran. Teknik pengumpulan data berupa tes dan observasi. Tes digunakan untuk melihat hasil belajar mahasiswa setiap siklus, sedangkan observasi untuk melihat aktivitas mahasiswa di dalam kelas. Data hasil tes digunakan untuk melihat peningkatan hasil belajar yang diperoleh mahasiswa. Data hasil temuan observer kemudian dianalisis untuk melihat aktivitas mahasiswa dalam pembelajaran.

\section{HASIL DAN PEMBAHASAN}

Open lesson pertama dilaksanakan pada hari Kamis, 05 Oktober 2017. Perkuliahan diikuti oleh 32 orang dari mahasiswa dan diamati oleh tiga orang observer, yaitu: Dr. Sri Widayati, M.Hum, Ibu Rulik Setiani, M.Pd., dan Ibu Rini Susilowati, M.Pd. Materi yang dibahas dalam perkuliahan, yaitu mengenai Proposisi. Fokus yang diamati, yaitu aktivitas mahasiswa dalam pembelajaran.

Pada tahap plan, tim melakukan perencanaan pembelajaran, media pembelajaran, lembar kerja mahasiswa dan jumping task yang akan digunakan pada pembelajaran. Selain itu, pada tahap plan juga dilakukan evaluasi perangkat pembelajaan yang telah dibuat oleh dosen model seperti lessson design, lembar kuis, dan jawaban latihan soal.

Selanjutnya pada tahap pelaksanaan (do) proses pekuliahan berlangsung menggunakan model pembelajaran Team Assisted Individualization (TAI). Pada awalnya mahasiswa diminta berkelompok sesuai dengan hasil pretes yang dilakukan pada pertemuan sebelumnya. Mahasiswa diberi stimulus mengenai pengertian proposisi dan kemudian mulai mengerjakan tes keterampilan yang terdapat pada lembar kerja mahasiswa secara individu. Setelah semua anggota kelompok selesai mengerjakan tes keterampilan, dilanjutkan dengan diskusi hasil jawaban individu dalam kelompok. Setelah itu, mahasiswa menyelesaikan tes kedua pada LKM kemudian dilanjutkan dengan dikusi kelas mengenai jawaban hasil tes. Setelah diberi penguatan, mahasiswa 
diminta kembali untuk mengerjakan Tes Unit 1.

Pada tahap refleksi (see) disampaikan hasil temuan dari para observer. Adapun hasil refleksi adalah sebagai berikut.

1. Terdapat kelompok yang sudah berdiskusi dengan baik, yaitu kelompok

1. Namun, sebagian besar kelompok masih belum terbiasa belajar dalam kelompok.

2. Beberapa mahasiswa masih belum terbiasa dengan model pembelajaran TAI sehingga masih bingung dalam mengerjakan tugas yang terdapat pada LKM.

3. Meskipun pertama kali dilakukan lesson study, mahasiswa tidak terganggu dengan kehadiran beberapa observer di dalam kelas.

4. Terdapat beberapa mahasiswa yang hanya diam dan belum antusias dalam proses pembelajaran, ketika mahasiswa yang lain bersemangat untuk menyampaikan hasil kerjanya.

5. Kelompok 8 kurang aktif dalam pembelajaran diduga karena posisi duduk yang berada di belakang.

6. Pada saat mengerjakan tes unit 1 , masih ada beberapa mahasiswa yang bertanya kepada temannya, padahal seharusnya tes dikerjakan secara individu.

Selanjutnya, open lesson kedua dilaksanakan pada hari Kamis, 12 Oktober 2017 dengan materi proposisi majemuk dan ekspresi logika. Pada perkuliahan kali ini diikuti oleh 43 mahasiswa dan dua orang observer, yaitu Ibu Rulik Setiani, M.Pd., dan Ibu Rini Susilowati, M.Pd.

Pada tahap perencanaan (plan), tim membuat lesson design berdasarkan hasil refleksi dari open lesson yang pertama. Pada proses pembelajaran, mahasiswa yang kurang aktif akan diminta untuk menyampaikan pendapat atau hasil kerjanya. Selanjutnya lesson design dan LKM dievaluasi bersama para observer.

Pada tahap pelaksanaan (do) masih sama dengan open lesson yang pertama, pem belajaran masih menggunakan pembelajaran TAI. Pembelajaran diawali dengan dosen memberikan gambaran umum mengenai proposisi majemuk dan ekspresi logika. Kemudian mahasiswa mulai menentukan ekspresi logika dari suatu proposisi majemuk. Setelah itu, mahasiswa diminta untuk menentukan proposisi yang telah diketahui ekspresi logikanya. Permasalahan tersebut diselesaikan secara individu. Beberapa mahasiswa diminta untuk menyampaikan hasil kerjanya, untuk kemudian dibahas secara klasikal. Untuk mengatasi masalah ke-4 pada see tahap pertama, mahasiswa yang kurang aktif pada pertemuan sebelumnya diminta untuk menyampaikan hasil kerjanya. Langkah akhir pembelajaran, mahasiswa diminta untuk mengerjakan tes unit 2. Sebelum pembelajaran berakhir, disampaikan bahwa 
pada pertemuan selanjutnya akan dibahas materi mengenai tabel kebenaran.

Setelah dilakukan tahap do, selanjutnya dilakukan tahap see. Secara umum, open lesson kedua hampir sama dengan open lesson sebelumnya. Mahasiswa yang sebelumnya kurang antusias sudah lebih antusias dalam belajar. Proses diskusi sudah berjalan lebih baik. Namun, pada kelompok 8 ternyata masih mengalami permasalahan yang sama. Hal ini diduga karena posisi kelompok yang berada di belakang. Kemudian, untuk kelompok 9 dan 10 meskipun berada di belakang tetap antusias dalam mengerjakan LKM. Artinya, perlu perlakuan khusus untuk kelompok 8 pada open lesson ketiga. Pada open lesson kali ini, mahasiswa terlihat jenuh karena terlalu banyaknya jumlah soal pada tiap-tiap tes yang harus diselesaikan. Selain itu, karena terdapat 11 kelompok, kelas terlihat padat apalagi tata letak kelompok yang kurang baik.

Open lesson ketiga dilaksanakan pada hari Kamis, 19 Oktober 2017 dengan materi menentukan Tabel Kebenaran dari suatu proposisi. Pada perkuliahan kali ini diikuti oleh 46 mahasiswa dan dua orang observer, yaitu Dr. Sri Widayati, M.Hum. dan Ibu Rini Susilowati, M.Pd.

Pada tahap perencanaan, berdasarkan hasil see pada open lesson kedua, banyaknya jumlah soal pada tugas dikurangi agar mahasiswa tidak merasa jenuh. Selanjutnya lesson design dan LKM kemudian dievaluasi bersama dengan para observer.
Pada tahap do, diawali dengan membagikan LKM kepada tiap siswa. Pada pertemuan tersebut terdapat tambahan jumlah mahasiswa sehingga menyebabkan tiga maha siswa tidak mendapatkan LKM. Namun dengan sigap, mahasiswa yang tidak mendapatkan LKM lalu bergabung dengan teman sekelompoknya. Mahasiswa kemudian diminta untuk memahami ringkasan materi yang terdapat pada LKM untuk selanjutnya mulai menyelesaikan tes keterampilan secara individu. Hasil kerja individu didiskusikan secara berkelompok dan dibahas secara klasikal. Selanjutnya mahasiswa menyelesaikan jumping task pada tes 2 dan dilanjutkan dengan pembahasan secara klasikal. Mahasiswa kemudian mengerjakan tes unit 3.

Adapun hasil refleksi pada open lesson ketiga, karena kurangnya komunikasi dosen tidak mengetahui ada tambahan jumlah mahasiswa yang mengikuti perkuliahan. Hal ini berakibat ada mahasiswa yang tidak mendapatkan LKM. Meski demikian, mahasiswa yang tidak mendapat LKM masih antusias belajar dengan melihat soal pada LKM teman sekelompoknya. Kelompok 8 yang awalnya berada di belakang, posisinya ditukar dengan kelompok 1 yang berada di depan. Setelah pertukaran posisi, kelompok 8 terlihat aktif berdiskusi bahkan mereka telah menyiapkan materi pembelajaran sebelum perkuliahan dimulai. 
Pelaksanaan lesson study dalam berdiskusi dengan teman sekelompoknya juga pembelajaran pengantar logika telah semakin baik.

memberikan perbaikan pada proses pembelajaran. Pembelajaran yang semula teacher centered telah beralih ke student centered. Hal ini ditunjukkan dengan lebih tingginya ke- terlibatan mahasiswa dalam pembelajaran. Dosen hanya berlaku sebagai fasilitator, motivator, dan mediator. Dengan hanya sedikit informasi yang diberikan oleh dosen, mahasiswa dituntut untuk memahami materi lebih jauh dengan menyelesaikan permasalahan-permasalahan yang ada di LKM.

Pembelajaran dalam kelas besar membuat dosen sulit untuk mengamati aktivitas mahasiswa secara menyeluruh. Pembelajaran TAI yang membagi mahasiswa dalam beberapa kelompok kecil lebih memudahkan dosen melakukan kontrol terhadap aktivitas dan hasil belajar pengantar logika mahasiswa. Selanjutnya adanya observer dalam pembelajaran juga membantu dosen model untuk mengamati kelas secara menyeluruh.

Dari uraian di atas, dapat dinyatakan bahwa penerapan model pembelajaran TAI berbasis lesson study memberikan pengaruh pada aktivitas mahasiswa dalam pembelajaran. Berdasarkan hasil temuan para observer, terjadi peningkatan aktivitas mahasiswa dalam pembelajaran. Mahasiswa yang awalnya kurang aktif, sudah menunjukkan perubahan yang signifikan.

\section{Simpulan}

Berdasarkan hasil penelitian dan pembahasan, dapat dikatakan bahwa penerapan lesson study dengan model pembelajaran TAI dalam pembelajaran pengantar logika telah memberikan perbaikan pada proses pembelajaran. Pembelajaran yang semula teacher centered telah beralih ke student centered. Selanjutnya, lesson study memberikan pengaruh berupa peningkatan aktivitas mahasiswa dalam kegiatan pembelajaran khususnya pada mata kuliah pengantar logika. Dalam proses pembelajaran, dosen hanya sebagai fasilitator, dan mediator. Peran mahasiswa dalam pembelajaran semakin dominan.

\section{DAFTAR RUJUKAN}

JICA-FMIPA UPI. 2006. Lesson Study: Suatu Strategi untuk Meningkatkan Keprofesionalan Pendidik. IMSTEPJICA. UPI Press.

Rusman. 2011. Model-Model Pemebelajaran Mengembangkan Profesionalisme Guru. Bandung: Raja Grafindo Persada.

Slavin, Robert E. 2005. Cooperative Learning: Teori, Riset, dan Praktik. Bandung: Nusa Media.

Sugiyono. 2010. Metode Penelitian Kuantitatif Kualitatif Dan $R \& D$. Bandung: Alfabeta.

Selain itu, kemampuan mahasiswa untuk 
Sukirman. $2006 . \quad$ Peningkatan

Keprofesionalan Guru Melalui Lesson study. Makalah disajikan dalam Pelatihan Lesson study Bagi Guru Yamin, Martinis. 2013. Paradigma Baru Berprestasi dan MGMP MIPA SMP Pembelajaran. Jakarta: Referensi.

Seluruh Indonesia, Yogyakarta,26 November-10 desember 2006. 